\title{
EVALUATION OF HUMERAL IMMUNITY AGAINST THREE HYDATID CYST ANTIGENS OF CAMELS USING SECONDARY CYST DEVELOPMENT IN RABBIT MODEL
}

\author{
By \\ WALEED M. MOUSA, OLFAT A. MAHDY*, AZZA M. ABDEL-WAHAB \\ AND SOHAILA M. EL-GAMEEL
}

Department of Parasitology, Faculty of Veterinary Medicine, Cairo University, Giza, P.O. Box 12211, Egypt ( ${ }^{\star}$ Correspondence: dr.olfat.mahdy@gmail.com)

\section{Abstract}

Cystic echinococcosis (CE) is one of the commonest zoonotic parasitosis of worldwide distrib-ution. This study induced a protective immunity against secondary hydatidosis by using conven-tional vaccination approaches and evaluated the accompanied humeral immune response. For antigen preparation Hydatid cysts (HC) were collected from camels slaughtered at Cairo abattoir, during 2015. Three groups of male rabbits were immunized subcutaneously with crude Hydatid cyst fluid (CHCF), partially purified Hydatid cyst fluid (ppHCF) and protoscolices (PSC) antigens. After two boosters, rabbits were challenged intra peritoneally with 2000 viable protoscolices, and the humeral immune response was analyzed using ELISA. Percent of protection against $\mathrm{HC}$ was $93.0 \%, 88.4 \%$ and $86.0 \%$ in immunized rabbits with ppHCF, PSC and CHCF antigens respectively. Antibody level in immunized group with ppHCF antigen on day 28 was higher than before immunization and was higher than that in $\mathrm{CHCF}$ and PSC antigen groups. The results of this article indicate that ppHCF antigen can be used as a candidate for vaccine production.

Key words: Egypt, Hydatid cyst, Immunization, Antibody, ELISA, Hydatidosis, Histopathology

\section{Introduction}

Cystic echinococcosis is one of the most widespread parasitic zoonoses in the world that causes a huge public health problems and economic impacts in several countries (Babazadeh et al, 2015). In the Middle East and Arab North Africa from Morocco to Egypt was considered as one of the major zoonotic parasitosis (El-Madawy et al, 2011), caused by Echinococcus granulosus complex which is endemic parasite in some countries that have a large production of herbivores with usage of dogs as pasturage animals (Thompson et al, 2006). The developing stages of Echinoccocus spp is unaffected by the immune response. While the host immune system interacts against the juvenile intestinal stages or oncospheres and may lead to humeral immune response and production of specific antibodies (Eckert and Deplazes, 2004). Hydatidosis in the 1980s years was diagnosed by detection of specific antibody against it in the serum of infected host. These antibodies can be detected by using ELISA (Jenkins and Rickard, 1986). Proteins are probably the preferred choice of most researches on candidates for vaccine antigens preparation. As proteins proved easy to be identified, modified and produced economically in large quantities, for commercial vaccines production. In addition many proteins play key roles in parasite metabolism, so they may be a good target to disturb parasite biology if immune response rose against them (Hein and Harrison, 2005).

This study aimed to evaluate locally prepared three antigens from camel Hydatid cyst (HC); crude hydatid cyst fluid (CHCF), partially purified hydatid cyst fluid (ppHCF) and protoscolices (PSC) antigens. The immunological response against to antigens was evaluated by their effect on secondary $\mathrm{HC}$ development in rabbit model and detection of antibody titration using ELISA.

\section{Material and Methods}

Animal and parasite: Twenty male New Zealand white rabbits ( $2 \mathrm{Kg}$ in weight, 4 months old) were reared under good hygienic conditions (clean, well ventilated and warm place) and fed on a balanced diet. All rabbits were examined through coprological 
examination daily for 15 day to ensure that they were free from any parasite. Rabbits were randomly grouped into $5 \mathrm{gp}$ (4 rabbits each). The Hydatid cyst fluid (HCF) was aseptically aspirated from freshly collected $\mathrm{HC}$ of naturally infected camels. The fluid was centrifuged and PSC were collected, rinsed 5-8 times in a sterile phosphate buffer saline (PBS) $(\mathrm{pH}, 7.4)$ containing penicillin $(500 \mathrm{IU} / \mathrm{ml})$ and streptomycin $(100 \mu \mathrm{g} / \mathrm{ml})$ then examined microscopically for viability through flame cell activity. The PSC were re-suspended in PBS containing antibiotics (Hashemi Tabar et al, 2009).

Antigen preparation: Hydatid cysts were collected from the lung and liver of slaughtered camels at Cairo abattoir (El-Basatin), during 2015. The antigens were prepared (Maddison et al, 1989) for partially purified Hydatid cyst fluid antigen ( $\mathrm{ppHCF}$ ), Ramsy et al. (1999) for crude hydatid cyst fluid an-

Table 1: Immunization and challenge of differ

\begin{tabular}{|c|c|c|c|c|c|}
\hline \multirow{3}{*}{$\begin{array}{c}4 \text { Rab- } \\
\text { bits/ } \\
\text { group }\end{array}$} & \multicolumn{3}{|c|}{ Immunization and challenge } & \multirow{2}{*}{$\begin{array}{l}\text { Challenge/rabbit } \\
\text { (at } 28^{\text {th }} \text { day) }\end{array}$} & \multirow{2}{*}{$\begin{array}{l}\text { Necropsy } \\
\left(16^{\text {th }} \text { w.p.i. }\right)\end{array}$} \\
\hline & \multicolumn{2}{|c|}{ First immunization (at zero day) } & $\begin{array}{l}\text { Booster dose }\left(2^{\text {nd }} \text { at }\right. \\
14^{\text {th }} \& 3^{\text {rd }} \text { at } 21^{\text {th }} \text { day }\end{array}$ & & \\
\hline & Antigen & Dose/rabbit & Dose/rabbit & 2000 viable PSC & slaughtered and \\
\hline 1 & CHCF Ag & $2 \mathrm{ml}(100 \mu \mathrm{g}$ protein & $2 \mathrm{ml}(50 \mu \mathrm{g}$ protein in & intra peritoneal sus- & organs exam- \\
\hline 2 & ppHCF Ag & in mineral oil adju- & mineral oil adjuvant) & pended in $2 \mathrm{ml} \mathrm{PBS}$ & ined for cyst \\
\hline 3 & PSC Ag & vant) & & of penicillin & \\
\hline 4 & Adjuvant only & 2ml (PBS Adjuvant) & $2 \mathrm{ml}$ (in PBS) & (500IU/ml) \& strep- & \\
\hline 5 & control (INCG) & --- & --- & $\begin{array}{l}\text { tomycin }(100 \mu \mathrm{g} \\
/ \mathrm{ml}))\end{array}$ & \\
\hline
\end{tabular}

Ag: antigen

Necropsy procedure and determination of infection: Rabbits were slaughtered on the $16^{\text {th }}$ W.P.I. The different muscles, all visceral organs and their surrounding membranes particularly lung, liver, kidney, heart and spleen were examined macroscopically according to procedures of FAO (1994). Cyst load was calculated according to Al-Qaoud and Abdel-Hafez (2005) by multiplying the number of cysts with the average size of cysts for each group expressed in millimeters. Percentage of protection $=1$ - (mean number of cysts in test group/mean number of cysts in the non-immunized control group $\mathrm{x} 100$ (Dempster et al, 1995). Statistical analysis of the obtained results was carried out with ANNOVA test. Collected HC were fixed in neutral-buffered formalin in $10 \%$. tigen (CHCF) and Ahmed et al. (2001) for protoscolix antigen (PSC). The protein content of prepared antigens was measured using Lowry's assay (Lowry et al, 1951).

Immunization and Challenge: Rabbits in G1, G2 \& G3 were immunized with CHCF, ppHCF and PSC antigens respectively. The G4 (adjuvant group (Adj)) were injected with PBS and adjuvant only. Second and third immunization were conducted at $14^{\text {th }} \&$ $21^{\text {th }}$ day post first immunization using same preparation. The G5 were used as infected non immunized control group (INCG). One week after the third immunization, each rabbit in all groups was challenged with 2000 PSC intraperitoneally (Ito et al, 2001). Blood samples were collected from the ear vein of rabbits at $0,2,4,6,8,10,12,14 \&$ 16 weeks post immunization (w.p.i) (12 weeks post challenge) for further serological studies (ELISA).

Determination of antibody titer: ELISA was used (De Savgny et al, 1979). The E. granulosus antigens prepared from camel were optimally diluted in coating buffer (carbonate - bicarbonate buffer, $\mathrm{pH}$ 9.6) and used $200 \mu \mathrm{l} /$ well to coat. Tested sera were added $100 \mu \mathrm{l} /$ well at different dilutions starting with $1 / 100,1 / 200$ up to $1 / 3200$. Protein -A IgG Horseradish peroxidase conjugate (diluted 1/2000) in PBS was added. The optical density (OD) values were read in a micro-ELISA reader system at $450 \mathrm{~nm}$.

Histopathological changes: Collected HC from experimentally infected rabbits were fixed in neutral-buffered formalin $10 \%$, and examined (Carleton et al, 1967).

Statistical analysis: Data were tabulated, computerized and analyzed using analysis of variance (ANNOVA test) and (Scheffe test) where, $\mathrm{P}$ - value $<0.01=$ significant variation. 


\section{Results}

The immunized groups (Igp) with $\mathrm{CHCF}$ and ppHCF and PSC antigens, out of 4 rabbits in each group 2 were found to be infected (50\% reduction in established infection). While all rabbits in Adj and INCG were infected with HC (zero reduction in established infection).

Total number and average size of cysts in the three Gs were lower than that of Adj \& INCG. Highest number of cysts was six in $\mathrm{CHCF}$ followed by five in PSC and the low was three in ppHCF. One was the low number per rabbit was in ppHCF and PSC group and the high was in four/rabbit in CHCF, but control group showed 18 cysts/ rabbit. The average cyst' size in the three Gs was $0.5-3 \mathrm{~mm}$; large $(4 \mathrm{~mm})$ in $\mathrm{CHCF}$ and small $(0.5 \mathrm{~mm})$ in $\mathrm{ppHCF}$ antigen. Cyst load was high in CHCF group (12mm) and low in ppHCF group $(3.75 \mathrm{~mm})$.

Cysts were embedded in internal organs as liver, urinary bladder, intestine, stomach and spleen in Adj \& INCG. In the three groups' cysts were distribution in the omentum, diaphragm and near heart in immunized rabbits. Cysts of groups were collapsed and retarded in its normal growth in comparison with the cysts of INCG \& Adj that were more fluidly

Table 2: parameters of HC in different animal groups.

\begin{tabular}{|c|c|c|c|c|c|c|c|c|c|}
\hline \multirow{2}{*}{$\begin{array}{l}\text { Animal } \\
\text { Group }\end{array}$} & \multicolumn{4}{|c|}{ Cysts No. in individual rabbits } & \multirow{2}{*}{$\begin{array}{l}\text { Cysts / } \\
\text { group }\end{array}$} & \multirow{2}{*}{$\begin{array}{c}\text { Mean cysts } \\
\text { / animal }\end{array}$} & \multirow{2}{*}{$\begin{array}{l}\text { Average size of } \\
\text { cysts }(\mathrm{mm} .)\end{array}$} & \multirow{2}{*}{$\begin{array}{l}\text { Cyst /group } \\
(\mathrm{mm} .)\end{array}$} & \multirow{2}{*}{$\begin{array}{c}\% \text { of pro- } \\
\text { tection }\end{array}$} \\
\hline & $\mathrm{R} 1$ & $\mathrm{R} 2$ & R3 & $\mathrm{R} 4$ & & & & & \\
\hline 1 & 4 & 2 & - & - & 6 & 1.5 & $1-3$ & 12 & 86.0 \\
\hline 2 & 1 & 2 & - & - & 3 & 0.75 & $0.5-2$ & 3.75 & 93.0 \\
\hline 3 & 4 & 1 & - & - & 5 & 1.25 & $1-2$ & 7.5 & 88.4 \\
\hline 4 & 9 & 7 & 8 & 7 & 31 & 7.75 & $0.5-4$ & 69.75 & 27.9 \\
\hline 5 & 18 & 7 & 6 & 12 & 43 & 10.75 & $1-8$ & 193.5 & 0.0 \\
\hline
\end{tabular}

R: rabbit immunized rabbit with CHCF antigen or ppHCF antigen or PSC antigen or Adj. or INCG, Size: cyst from 2 opposite directions.

Antibodies produced in three rabbit Gs immunized with CHCF, ppHCF or PSC antigens was high than in controls. Antibodies appeared at 2 W.P.I and reached a peak at 4 W.P.I (a week after $3^{\text {rd }}$ immunization) antibody level in ppHCF antigen was high (sample to positive $(\mathrm{s} / \mathrm{p})$ ratio $=1.652)$ fol-

Table 3: S/P ratio of ELISA for the sera (1/ 100 dilution) from three immunized rabbit and control groups

\begin{tabular}{|c|c|c|c|c|}
\hline (W.P.I.) & CHC-G & ppHCF-G & PSC-G & INC-G \\
\hline 0 & 0.099 & 0.089 & 0.056 & 0.045 \\
\hline 2 & 0.759 & 0.986 & 0.804 & 0.099 \\
\hline 4 & 1.517 & 1.652 & 1.629 & 0.156 \\
\hline 6 & 1.219 & 1.565 & 1.499 & 0.512 \\
\hline 8 & 0.837 & 1.414 & 1.365 & 0.567 \\
\hline 10 & 0.765 & 1.023 & 1.010 & 0.671 \\
\hline 12 & 0.723 & 0.972 & 0.918 & 0.710 \\
\hline 14 & 0.551 & 0.890 & 0.870 & 0.527 \\
\hline 16 & 0.522 & 0.832 & 0.792 & 0.396 \\
\hline
\end{tabular}

S/P ratio: mean optical density of sample - mean optical density of negative sample /mean optical density of positive samplemean optical density of negative sample. S/P ratio $>0.5=$ a positive

Histopathological examination of some representative sections of liver showed HC under the surface of liver capsule, embedded in the underlying liver tissue. Cyst was infiltrated by inflammatory cells mostly mononuclear cells and encapsulated by fibrous connective tissue. Hepatocytes beneath cyst showed necrobioteic changes from vacuolar lowed by PSC antigen ( $\mathrm{s} / \mathrm{p}$ ratio=1.629), then $\mathrm{CHCF}$ antigen $(\mathrm{s} / \mathrm{p}$ ratio=1.517). Antibody in sera from Adj and INCG appeared on the $6^{\text {th }}$ W.P.I $(\mathrm{s} / \mathrm{p}$ ratio $=0.512)$ and increased gradually till $12^{\text {th }}$ W.P.I $(\mathrm{s} / \mathrm{p}$ ratio= $0.710)$ and decreased on the $14^{\text {th }}$ W.P.I ( $/ \mathrm{p}$ ratio $=0.527$ ) till the experimental end. degeneration to coagulative hepatic cell necrosis which was characteristically showed in hepatocytes surrounding cyst. Other section was surrounded with laminated layer with abundant degenerative calcific structure of calcareous corpuscles. 


\section{Discussion}

A range of different antigens including cystic fluid (Al-Qaoud and Abdel-Hafez, 2005) and protoscolex (Hernandez and Nieto, 1994) were used as vaccines candidates.

In the present study, the $1^{\text {st }}$ assessment (necropsy procedures and cyst evaluation) gave variations between the immunized and the controls. In the group with $\mathrm{CHCF}$ and ppHCF and PSC antigens, out of 4 rabbits in each group 2 were found to be infected (50\% reduction in established infection). While all rabbits in Adj and INCG were infected with $\mathrm{HC}$. The highest protection rate (93.0\% decrease in cyst load) in immunized animals with ppHCF antigen followed by PSC \& CHCF antigens $(88.4 \%$ \& $86.0 \%$ reduction in cyst load, respectively.) These results agreed with Al-Qaoud and AbdelHafez (2005) who found that, mice immunized with antigen $\mathrm{B}$ (purified $\mathrm{HCF}$ antigen) prepared from sheep cysts showed a significant level of protection $(98.3 \%$ reduction in cyst load) followed by CHCF and PSC antigens with $79 \% \& 71 \%$ protection rate respectively. Hashemi Tabar et al. (2007) who recorded that lamb immunization with $\mathrm{HCF}$ antigen showed protection rate $(75.75 \%)$ higher than that immunized with PSC $(54.5 \%)$.

In the present study, secondary $\mathrm{HC}$ were developed in the omentum, diaphragm and near heart in immunized rabbits. This result agreed with El-Kattan (2017) who found that cysts were mostly distributed in the peritoneal cavity. Presently, in Adj and INCG groups the developed HC were embedded in or adjacent to all internal organs as liver, while chest cavities were free from infection. These results agreed with Theodorides et al. (2001) who recorded the same results.

These variations in cysts' number and distribution might be related to the route and type of developmental stage used for infection Mousa and El-Massry (1999). Also, Zhang et al. (2001) recorded different degrees of protection against secondary infection when used a primary infection with onchospheres injected by different routes.

In the present study, the $2^{\text {nd }}$ assessment of protection (humeral immune response), showed that antibody level in three immunized groups appeared at $2^{\text {nd }}$ W.P.I and reach to its peak at $4^{\text {th }}$ W.P.I (one week after third immunization) as antibody level was about 11 time higher than before immunization. Antibody level in ppHCF antigen was the highest followed by PSC antigen then $\mathrm{CHCF}$ antigen. This result agreed with Youssef $e t$ al. (2010) who found that, the mice immunized with purified hydatid fluid antigen produced higher antibody levels than that mice immunized with PSC antigen on the $4^{\text {th }}$ and $8^{\text {th }}$ W.P.I. Also, Al-Qaoud et al. (2008) reported that the highest level of IgG1 was recorded in $\mathrm{AgB}$ immunized mice followed by low but protective antibody level in immunized mice with CHF and PSC antigens. Hashemi Tabar and Razmi (2009) recorded that the level of antibody in immunized mice with $E$. granulosus adult on day $28^{\text {th }} \& 49^{\text {th }}$ post immunization was higher than in mice immunized with HCF \& PSC antigens. On contrary El-Kattan (2017) reported that the level of antibodies produced in response to $\mathrm{CHCF}$ antigen was higher than in ppHCF \& PSC antigens. Also, Hernandez and Nieto (1994) found that PSC produced high level of antibodies against infection in mice. This variable responses and protection rates were explained by using the different antigen preparations from different antigen sources of variable purities (Al-Qaoud et al, 2008).

Cysts of three gtoups were collapsed and retarded in its normal growth in comparison with the cysts of the INCG that were more fluidly. Histopathological examination of cysts and surrounding tissues confirmed the results. It showed presence of $\mathrm{HC}$ under the surface of liver capsule embedded in the underlying liver tissue. The cyst was infiltrated by inflammatory cells mostly mononuclear cells and encapsulated by fibrous connective tissue. Other sections were surrounded with laminated layer. Also, abun- 
dant degenerative calcific structure of calcareous corpuscles was seen. These results agreed with El-Kattan (2017) who found that the collected cysts were collapsed and retarded in its normal growth in apart of immunized rabbit groups and fluid in others.

Generally speaking, in Egypt human hydatidosis was well documented in many governorates (Abdalla et al, 1975; Bebars et al, 1987; Romia et al, 1992; Madwar et al, 1995; Mazyad et al, 1998; 1999; Ramzy et al, 1999; El Shazly et al, 2001; Sadaka et al, 2002; Kandeel et al, 2004; Dyab et al, 2005; Abbas et al, 2006; El-Sebaie et al, 2006; Ibrahim et al, 2007; El Wakil et al, 2007), edible animals (El Kordy, 1946; Hamdy et al, 1980; El-Ridi et al, 1983; Ahmed, 1991; Abdel Rahman et al, 1992; Lotfi et al, 1994; Mohamed et al, 1997; Haridy et al, 1998, 2000; Abdel-Alim et al, 1999, Dyab et al, 2005) and in street dogs (Selim, 1967; Abou-Eisha and Abdel-Aal, 1995; El Shazly et al, 2007; Mazyad et al, 2007). Echinococcosis rate in the stray dogs ranged between $4.6 \%$ and $10.2 \%$. Dogs are domestic animals used to tend sheep and goats, and pet dogs enjoy a more intimate contact with man than other animals or birds (Haridy et al, 1998).

\section{Conclusion}

No doubt, echinococcosis and hydatidosis are economic and public health problem. Necropsy and ELISA results showed controversial relationship between number of the developed secondary $\mathrm{HC}$ and antibody level. As the number of cysts was the lowest in ppHCF antigen (3 cysts) followed by PSC (5 cysts) then CHCF group (6 cysts). Antibody level was the highest in ppHCF antigen $(\mathrm{s} / \mathrm{p}$ ratio $=1.652)$ followed by PSC antigen $(\mathrm{s} / \mathrm{p}$ ratio $=1.629)$ then $\mathrm{CHCF}$ antigen $(\mathrm{s} / \mathrm{p}$ ratio=1.517). The $\mathrm{ppHCF}$ antigen was the best antigen that induced a protective immunity aganist secondary hydatidosis in rabbit model through reduction in number of the developed cysts and the enhancement of production of the highest antibodies titer. So using ppHCF antigen is a candidate for vaccine production locally.

\section{References}

Abbas, M, Nafeh, AI, Youssef, YF, Nasr, M M, Radwan, HS, 2006: Conservative versus radical surgery for treatment of uncomplicated hepatic hydatid cysts. J. Egypt. Soc. Parasitol. 36, 2:559-76

Abdalla, H, Bahnansy, A, Sarwat, A, El-Zaher, H, 1975: Experience with hydatid disease. Ain-Shams Med. J. 26:612-20.

Abdel Rahman, MS, Sokkar, SM, Ahab, S, 1992: Comparative studies on hydatidosis in farm animals in Egypt. Deut. Tierartz. Wochensch. 99:438-40.

Abdel-Alim, KM, El-Gohary, AH, Samaha, H A, Draz, AA, 1999: Zoonotic parasitosis among some farm animals. Zagazig Vet. J. 27:103-12.

Abou-Eisha, AM, Abdel-Aal, AA, 1995: Prevalence of some zoonotic parasites in dog fecal deposits in Ismailia city. Assuit Vet. Med. J. 33: 119-26.

Ahmed, G, Nizami, WA, Saifullah, MK, 2001: Analysis of potential antigens of protoscolices isolated from pulmonary and hepatic hydatid cyst of Bubalus bubalis. Comp. Immun. Microbiol. Infect. Dis. 24:91-110.

Ahmed, LS, 1991: Incidence of hydatid disease in camels slaughtered at Assiut abattoir. Assiut Univ. Vet. Med. J. 24:74-8.

Ahmed, LS, 1991: Incidence of hydatid disease in camels slaughtered at Assiut abattoir. Assiut Univ. Vet. Med. J., 24: 74-78.

Al-Qaoud, KM, Abdel-Hafez, SK, 2005: $\mathrm{Hu}-$ moral and cytokine response during protection of mice against secondary hydatidosis caused by Echinococcus granulosus. Parasitol. Res. 98, 1: 54-60.

Babers, MA, Fayad, ME, Arafa, MA, 1987: The incidence of hydatidosis among populations in Suez Canal Zone. J. Egypt. Soc. Parasitol. 17, 2:377-80.

Carleton, MA, Durry, R, Willington, E, Cammeron, H, 1967: In: Comparative Cytotoxicity of Secondary Hydatid Cysts, Protoscoleces, and in Vitro Developed Micro-cysts of Echinococcus granulosus: Carleton's histological technique, $4^{\text {th }}$ Ed. Oxford Univ. Press New York.

Dyab, KA, Hassanein, R, Hussein, AA, Metwally, SE, Gad, HM, 2005: Hyadtidosis among man and animals in Assuit and Aswan Governorates. J. Egypt. Soc. Parasitol. 35, 1:157-66.

El Kordy, MI, 1946: On incidence of hydatid disease in domestic animals in Egypt. J. Roy. Egypt. Med. Ass. 29:265-70. 
El Shazly, AM, Awad, SE, Abdel Tawab, AH, Haridy, FM, Morsy, TA, 2007: Echinococcosis (zoonotic hydatidosis) in street dogs in urban and rural areas, Dakahlia Governorate, Egypt. J. Egypt. Soc. Parasitol. 37, 1: 287-98.

El Shazly, AM, Soliman, M, El-Kalla, MR, Rezk, H, Nemr, HE, et al, 2001: Study of soluble adhesion molecules in some intestinal and tissues helminthes. J. Egypt. Soc. Parasitol. 31, 2:501-9.

El Wakil, HS, Ali, NM, Talaat, RM, Osman, W, 2007: Impact of experimental duel infections with Schistosoma mansoni and Echinoccocus granulosus on hepatic histopathology. J. Egypt. Soc. Parasitol. 37, 3:S1175 -88.

El-Kattan, AM, 2017: Some studies on hydatidosis in camels. (In Press).

El-Madawy, RS, Khalifa, NO, Afify, JSA, 2011: Epidemiological and molecular studies of hydatid cyst in slaughtered cattle and sheep in Toukh, Egypt. Benha Vet. Med. J. 1: 95-101.

El-Ridi, AMS, Arafa, MS, Abu-Senna, HO, Michael, SA, Rashid, SM, 1983: Hydatid infection in some animals in Egypt. J. Egypt. Soc. Parasitol. 13, 1:198-208

El-Sebaie, SB, El-Sebae, MMA, Esmat, ME, Majid, M, Nasr, MM, et al, 2006: Modified endocystectomy versus pericystectomy in Echinococcus granulosus liver cysts: a randomized controlled study, and the rule of specific antihydatid IgG4 in detection of early recurrence. J. Egypt. Soc. Parasitol. 36, 3:995-1008.

FAO/UNEP/WHO, 1994: Guidelines for Echinococcosis/ Hydatidosis Surveillance, Prevention and Control. Rome, No.29

Hamdy, II, Mikhail, EA, Soliman, AA, Hamed, HH, 1980: A study on hydatidosis in some animals in Egypt. J. Egypt. Soc. Parasitol. 10, 1:43-51.

Haridy, FM, Ibraheim, BB, Morsy, TA, 1998: Studies on hydatidosis in slaughtered camels in Egypt. J. Egypt. Soc. Parasitol. 28, 2:673-81.

Haridy, FM, Ibraheim, BB, Morsy, TA, 2000: Sheep-dog-man: The risk of zoonotic cycle in hydatidosis. J. Egypt. Soc. Parasitol. 30, 2:4239.

Hashemi Tabar, GR, Razmi, GR, 2009: Evaluation of antibody against hydatid fluid, protoscolex and adult worms of Echinococcus granulosus antigens by ELISA in mice. Iranian J. Vet. Sci. Tech.1, 1:27-34.

Hashemi Tabar, GR, Razmi, GR, Naghibi, A, 2007: Immunization of lambs against infection with Echinucoccus granulosus using protoscolices and Hydatid fluid antigens. J. Vet. Res. 62, 4:77-81.

Hein, WR, Harrison, GBL, 2005: Vaccines against veterinary helminthes. Vet. Parasitol. 132: 217-22.

Hernandez, A, Nieto, A, 1994: Induction of protective immunity against murine secondary hydatidosis. Parasite Immunol. 1, 16:537-44.

Ibrahim, BB, Haridy, FM, Hegazi, MM, Morsy, TA, 2007: Human hydatidosis granulosus in Greater Cairo, Egypt: With general review. J. Egypt. Soc. Parasitol. 37, 2:681-8.

Ito, A, Kanazawa, T, Nakao, M, Sako, Y, Ishikawa, Y, et al, 2001): Comparison of the antigenicity of protoscoleces and micro vesicles of Echinococcus multilocularis prepared from rats. J. Helminthol. 75, 4: 355-8.

Jenkins, DJ, Rickard, MD, 1986: Specificity of scolex and oncosphere antigens for the serological diagnosis of taeniid cestode infections in dogs. Aust. Vet. J. 63:40-2.

Kandeel, A, Ahmed, ES, Helmy, H, Setouhy, M, Craig, PS, Ramzy, RM, 2004: A retrospective hospital study of human cystic echinococcosis in Egypt. East Medit. Hlth. J. 10, 3:349-57.

Lotfi, A, El-Khateib, T, Fathi, S, Youssef, H, Said, M,1994: Incidence of hydatid cysts in camels slaughtered in Upper Egypt. Assiut Vet. Med. J. 31:200-8.

Lowry, OH, Rosenbrough, NJ, Farr, AL, Randall, RJ, 1951: Protein measurement with Folin-Phenol reagent. J. Biol. Chem. 193:265-75.

Maddison, SE, Slemenda, SB, Schaniz, P M, Fried, JA, Wilson, M, et al, 1989: A specific diagnostic antigen of E. granulosus with an apparent molecular weight of $8 \mathrm{KDa}$. Am. J. Trop. Med. Hyg. 40, 4: 377-83.

Madwar, MA, Kamal, SM, El-Gozamy, BR, 1995: Hydatid cyst of the parotid gland. $1^{\text {st }}$ Inter. Cong. Zoo. Parasitosis. November 20-23, Cairo.

Mazyad, MAM, Morsy, TA, Habib, KSM, 1999: Vertebral unilocular hydatidosis in a shepherd and his wife. J. Egypt. Soc. Parasitol. 29, 2:547-50.

Mazyad, MAM, Mostafa, MM, Morsy, TA, 1998: Spinal cord hydatid cysts in Egypt. J. Egypt. Soc. Parasitol. 28, 3:655-8.

Mazyad, SAM, Mahmoud, LH, Hegazy M. M, 2007: Echinococcosis granulosus in stray dogs and Echino-IHAT in the hunters in Cairo, Egypt. J. Egypt. Soc. Parasitol. 37, 2: 523-32. 
Mohamed, SA, Abdel-Hasseeb, SM, Bayo-mi, AH, 1997: Incidence and pathology of lung hydatidosis in slaughtered Camelus dromedaries at Assiut Governorate. Beni-Suef Vet. Med. Res. 7:173-87.

Mousa, WM, El-Massry, AA, 1999: Some biological and serological studies on hydatidosis in experimentally infected rabbits. Assiut Vet. Med. J. 41, 82:33-42.

Ramzy, RMR, Helmy, H, El.zayyat, E, Rifaat, MMA, Abdel Hameed, DM, Abdel Baki, MH, 1999: An enzyme-linked immunosorbent assay for detection of IgGI antibodies specific to human cystic echinococcosis in Egypt. Trop. Med. Inter. Hlth. 4, 9:616-20.

Romia, SA, Youssef, ME, Handousa, AE, Rizk, HM, Sallam, SM, 1992: Dot-ELISA as a diagnostic test in hydatid disease. J. Egypt. Soc. Parasitol. 22, 3:603-10.

Sadaka, HAH, Khalifa, AM, Zein Eldein, S, Taha, SKh, Mohy-Eldein, Kh, 2002: Urinary antigen detection for diagnosis of hydatid disease. J. Egypt. Soc. Parasitol. 32, 1:69-78
Selim, MK, 1967: Studies on some helminth parasites infecting dogs in Cairo and Giza, Egypt. Vet. Med. J. 17:37-48.

Theodorides, Y, Frydas, S, Rallis, T, Adamama, K, Papazahariadou, R, et al, 2001: MCP-1 and MIP-2 levels during Echinococcus granulosus infections in mice. J. Helminthol. 75, 2:2058.

Thompson, RCA, Boxell, AC, Ralston, BJC, Constantine, CC, Hobbs, RP, et al, 2006: Molecular and morphological characterization of Echinococcus in cervids from North America. Parasitol. 132:439-47.

Youssef, MR, Hosseini, SH, Hassan, ATM, 2010: Evaluation and comparison of immune response in laboratory model to low antigen of fluid and protoscolex in hydatid. Glob. Vet. 4, 6: 622-5.

Zhang, W, You, H, Zhang, Z, Turson, G, Hasyet, A. et al, 2001: Further studies on an intermediate host murine model showing that a primary Echinococcus granulosus infection is protective against subsequent oncospheral challenge. Parasitol. Int. 50, 4: 279-83.

\section{Explanation of figures}

Fig. 1: Parameters of hydatid cysts in different animal groups.

Fig. 2: S/P ratio of ELISA for the sera (1/100 dilution) obtained from three immunized rabbit and control groups

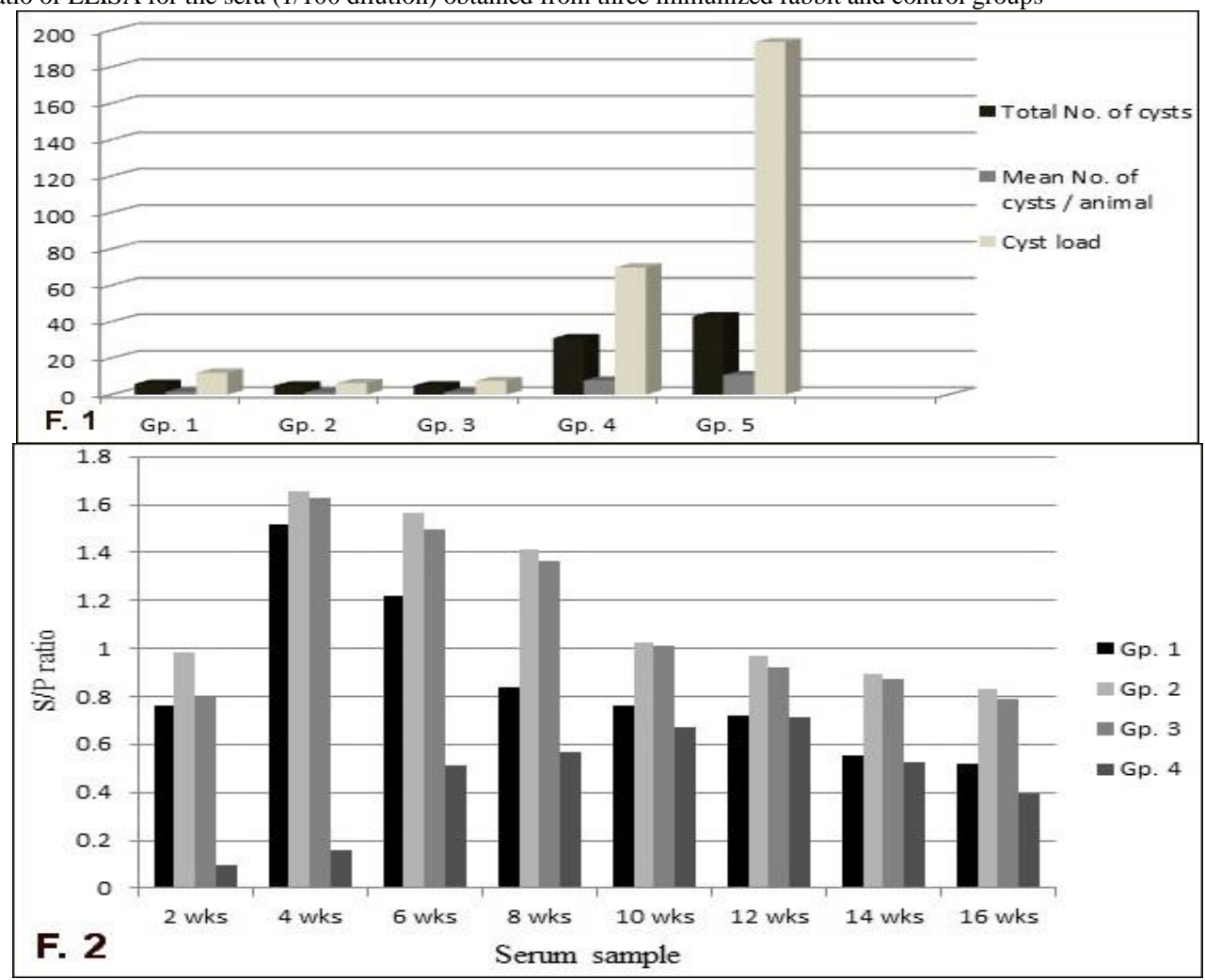




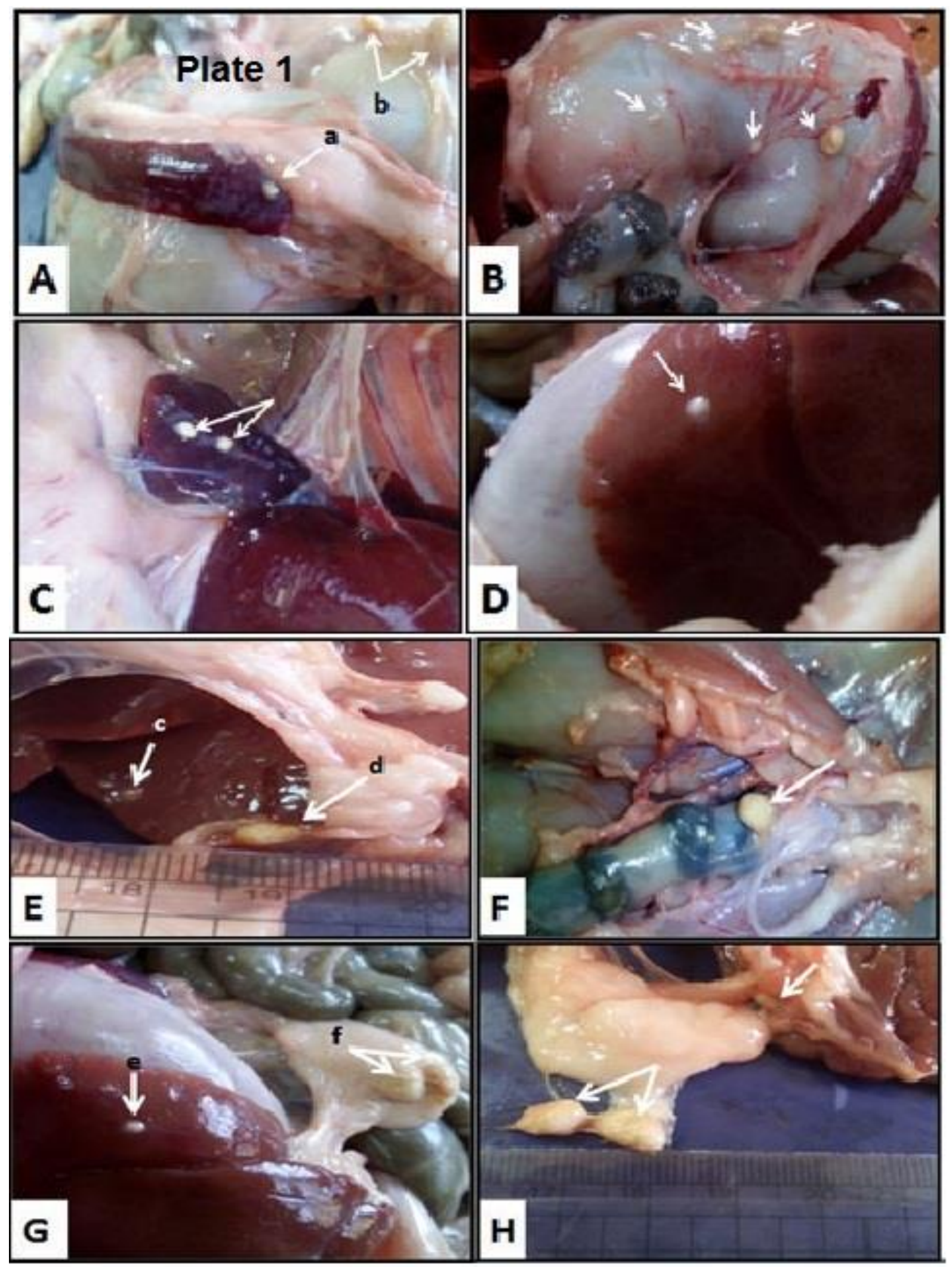

Plate 1: HC formed in infected non immunized control and AGs: A: show HC on spleen(a) and omentum (b) (arrow), B: showed HC on stomach (arrow), C\&D: showed HC on liver (arrow), E: showed HC on liver (c) omentum (d) (arrow), F: showed HC on intestine (arrow) G: showed HC on liver (e) omentum (f) (arrow), H: showed HC on omentum (arrow) 

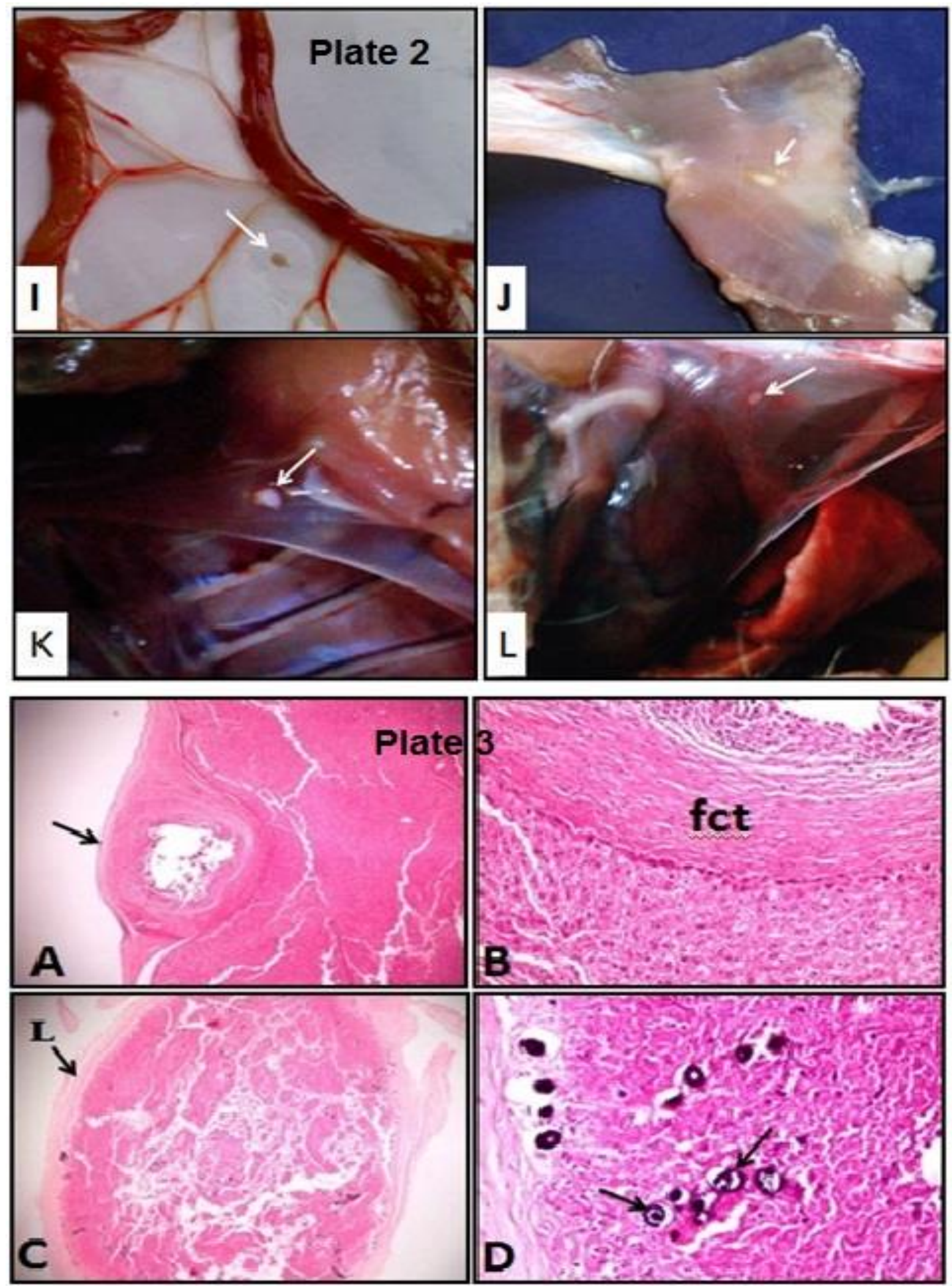

Plate 2: HC formed in immunized groups: I: HC in omentum (arrow), J: HC on diphragm (arrow), K\&L: HC on pericardium (arrow) Plate 3: Liver sections stained with H\&E. A: presence of hydatid cyst under surface of liver capsule and embedded in underlying liver tissue (arrow) (H\&E x4). B: hydatid cyst infiltrated by inflammatory cells mostly mononuclear cells and encapsulated by fibrous connective tissue. Hepatocytes beneath cyst revealed necrobioteic changes from vacuolar degeneration to coagulative cell necrosis (H\&E x20). C: Hydatid cyst surrounded with laminated layer (L) (arrow) (H\&E x4). D: Abundant degenerative calcific structure of Calcareous corpuscles (arrow) (H\&E $\mathrm{x} 20$ ). 